\title{
Alternatives to increase the red color of the peel in 'Daiane' and 'Venice' apples
}

\author{
Cristhian Leonardo Fenili ${ }^{1}$, José Luiz Petri², Cristiano André Steffens ${ }^{3}$, Mariuccia Schlichting de Martin ${ }^{4}$, \\ Cassandro Vidal Talamini do Amarante ${ }^{3}$, Angélica Schmitz Heinzen ${ }^{1}$
}

\begin{abstract}
This study aimed evaluate the effect of biostimulants, foliar fertilizers and ethephon on the red color in the peel of 'Daiane' and 'Venice' apples. The experiments were conducted in Caçador/SC, during 2015/2016 and 2016/2017 seasons. In 2015/2016, the treatments were: Control; Biostimulant I; Foliar fertilizer I + Foliar fertilizer II; Biostimulant II and KCl. In 2016/2017, was included the Ethephon treatment. In 2016/2017, Biostimulant I, Foliar fertilizer I + Foliar fertilizer II and Biostimulant II increased the percentage of 'Daiane' and 'Venice' apples with greater red peel cover, without affecting the quality and maturity of the fruits. In both cultivars, ethephon was treatment that promoted a higher percentage of apples in the category above $80 \%$ of red color. Ethephon increased red color intensity of 'Daiane' and 'Venice' apples, anthocyanin content, starch index, ethylene production and yellowing of background color of the fruits. The red coloration of 'Venice' apple peels is enhanced with ethephon, Biostimulant I and Foliar fertilizer I + Foliar fertilizer II and Daiane apples with ethephon, Foliar fertilizer I + Foliar fertilizer II and Biostimulant II.

Index Terms: Malus domestica, anthocyanin, biostimulants, foliar fertilizer, fruit quality
\end{abstract}

\section{Alternativas para incrementar a coloração vermelha da epiderme em maçãs 'Daiane' e 'Venice'}

Corresponding author: cristhianfenili@hotmail.com

Received: June 08, 2018 Accepted: September 21, 2018

Copyright: All the contents of this journal, except where otherwise noted, is licensed under a Creative Commons Attribution License.

\section{$($ (cc) $\mathbf{E Y}$}

Resumo- O objetivo deste trabalho foi avaliar o efeito de bioestimulantes, fertilizantes foliares e de etefon sobre a cor vermelha na epiderme de maçãs 'Daiane' e 'Venice'. Os experimentos foram conduzidos em Caçador/SC, durante as safras 2015/2016 e 2016/2017. Em 2015/2016, os tratamentos foram: Controle; Bioestimulante I; Fertilizante foliar I + Fertilizante foliar II; Bioestimulante II e KCl. Para a safra 2016/2017, foi incluído o tratamento Etefon. Em 2016/2017, Bioestimulante I, Fertilizante foliar I + Fertilizante foliar II e Bioestimulante II aumentaram os percentuais de maçãs 'Daiane' e 'Venice' com maior área de recobrimento da epiderme em vermelho, sem afetar a maturação dos frutos. Em ambas as cultivares, o etefon foi o tratamento que promoveu maior percentual de maçãs na categoria acima de $80 \%$ de cor vermelha. O etefon incrementou a intensidade da coloração vermelha das maçãs 'Daiane' e 'Venice', o teor de antocianinas, o índice de iodo-amido, a produção de etileno e o amarelecimento da cor de fundo dos frutos. A coloração vermelha da epiderme de maçãs 'Venice' é incrementada com etefon, Bioestimulante I e Fertilizante foliar I + Fertilizante foliar II e de maçãs 'Daiane' com etefon, Fertilizante foliar I + Fertilizante foliar II e Bioestimulante II.

Termos para Indexação: Malus domestica, antocianina, bioestimulantes, fertilizante foliar, qualidade de fruto.

${ }^{1}$ M.Sc., Agroveterinary Sciences Center, Santa Catarina State University. Lages-SC, Brazil. Emails: cristhianfenili@hotmail.com ${ }^{(0 R C I D}$ 00000003-4940-4789); angelica_heinzen@hotmail.com (ORCID 0000-0003-2558-9336)

${ }^{2}$ M.Sc., Researcher. Experimental Station. Caçador-SC, Brazil. Email: petri@epagri.sc.gov.br (ORCID 0000-0003-1485-7171)

${ }^{3} \mathrm{PhD}$, Professor. Santa Catarina State University, Lages, Brazil. Email: cristiano.steffens@udesc.br (ORCID 0000-0003-0936-8656); cassandro. amarante@udesc.br (ORCID 0000-0003-3448-734X)

${ }^{4} \mathrm{PhD}$, Researcher. Experimental Station. São Joaquim-SC, Brazil. Email: mariucciamartin@epagri.sc.gov.br (ORCID 0000-0002-6857-5594) 


\section{Introducion}

The visual quality of apples (color, size, shape and absence of defects) plays an important role in the national and international market, since it determines their commercial value (BLANKE, 2015). The first quality attribute evaluated by consumers is color, making it the most important attribute (CHEN et al., 2017). In Brazil, and in much of the world, the consumer preference is for apple with redder coloration, both regarding the fruit surface coverage and red color intensity. Only after visual analysis, the internal quality attributes of apples are considered, which can determine the consumer's buying frequency. Among them, the most important are crispness, taste, absence of disturbances and benefits of fruits on human health, especially due to the growing demand for foods containing functional compounds that prevent diseases (MUSACCHI; SERRA, 2018).

As apples mature, chlorophyll is degraded and carotenoid synthesis increases. At the same time, anthocyanins are expressively synthesized, giving the red color of fruits. Therefore, red and bicolored apples rely on the synthesis of anthocyanins to obtain coloration that provides high quality (HONDA, MORIYA, 2018). Anthocyanin biosynthesis pathway is well understood. Their genes are regulated by a complex series of interactions among genetic, environmental and plant management factors (MUSACCHI and SERRA, 2018).

Orchards with cultivars genetically inferior to accumulate anthocyanins, with excessive plant vigor, with unbalanced nutrition, management without vigor control, or even installed in regions with improper environmental conditions, with adverse climatic conditions such as excessive rainfall, cloudiness and high temperatures, compromise the red coloration of apple fruits. The main apple producing regions of Brazil present adverse climatic conditions for anthocyanin synthesis, with high temperatures at night and low thermal amplitude. Promising cultivars, such as 'Daiane' and 'Venice', with maturation period different from that of Gala and Fuji cultivars, and which are more adapted to the Brazilian climatic conditions for presenting less cold demand and resistance to the main pathogens of the apple culture, have bicolor pattern peel, and may present absence of red color in the shaded parts of fruits (KVITSCHAL; DENARDI, 2010; DE MARTIN et al., 2018).

In this context, several management techniques can be used to intensify light incidence in the apple tree canopy and to improve the red color of fruits, such as new management systems, green pruning, dwarf rootstocks, use of reflective mulch, fruit bagging, defoliation, thinning and irrigation (BLANKE, 2015). However, the use of these techniques requires manpower and / or the implantation costs are high and logistic difficulties do not compensate the financial return of the production of apples with better red coloration.

Management with foliar fertilizers, biostimulants and growth regulators to improve red color is an alternative that arouses interest due to the ease of execution and satisfactory results. Growth regulators that release ethylene in plants, such as ethephon, are effective in enhancing the red coloration of apples, stimulating the synthesis of anthocyanins (LI et al., 2017). Blanke (2016) reported that there are always new products on the market with high expectation to increase anthocyanin synthesis and consequently the red color of apples, mainly foliar fertilizers and biostimulants. Biostimulants based on plant extracts containing amino acids precursors of ethylene biosynthesis pathways and anthocyanins, chlorophyllase, potassium oxide and monosaccharide regulators, as well as foliar fertilizers, composed of minerals such as boron (B), may be accessible alternatives to improve the red coloration of apples. Amino acid precursors of the anthocyanin biosynthesis pathway may improve the red color of apples (SHAFIQ; SINGH, 2018). Potassiumbased products may increase the quality of apples, including the red coloration of the peel (NAVA; DECHEN; NACHTIGALL, 2008). B can increase the red coloration of apples, promoting the synthesis of ethylene (FALLAHI et al., 2010).

The aim of this work was to evaluate the effect of biostimulants, foliar fertilizers and ethephon on quality and maturation attributes, especially the red color in the peel of 'Daiane' and 'Venice' apples.

\section{Material and methods}

Experiments were conducted in experimental orchard, located in the municipality of Caçador / SC (latitude $26^{\circ} 46$ ' $\mathrm{S}$ and $51^{\circ} \mathrm{W}, 960$ meters a.s.l.) during the 2015/2016 and 2016/2017 seasons. Apple trees 'Daiane' and 'Venice' cultivars were used. Plants were grafted on M-9 and the planting density was 2,500 plants $\mathrm{ha}^{-1}$. All plants were conducted in the "central leader" system and managed according to recommendations of the integrated apple production system (SANHUEZA; PROTAS; FREIRE, 2006). The experimental design was in randomized blocks with six replicates. Each experimental unit consisted of three plants, from which the central plant was evaluated.

Treatments were applied during fruit maturation, about 30 days before the harvesting of the respective cultivars and, with the exception of ethephon (applied only once), treatments were reapplied three times, sequentially, every seven days (Table 1). Ethephon treatment was applied only in 2016/2017 to assist in the comparison among treatments.

All treatments were applied through leaves. Spraying was carried out during the morning between 8:00 
am and 9:00 am using a motorized costal spray with syrup volume equivalent to $1000 \mathrm{~L} \mathrm{ha}^{-1}$. Harvesting of 'Daiane' and 'Venice' cultivars took place on $02 / 29$ and $03 / 16$, respectively, in the $2015 / 2016$ season. In 2016/2017, 'Daiane' and 'Venice' cultivars were harvested on 03/03 and $03 / 16$, respectively.

After harvesting, all fruits of each replicate were submitted to red color coverage analysis, being subjectively classified into two categories $(>50 \%$ and $>80 \%$ red color). Subsequently, sample containing 25 fruits of each replicate, free of physiological disturbances, mechanical damages, diseases and pests, was evaluated for pulp firmness (PF), starch index (SI) and soluble solids content (SS). For the 2016/2017 season, color attributes (red and background color), titratable acidity (TA), respiratory and ethylene production rates, total phenolic compounds (CFT) and total anthocyanins (ANT) in fruit peel were also evaluated.

The determination of color attributes (red and background color) was performed with the use of colorimeter, model CR 400 (Konica Minolta ${ }^{\circledR}$, Tokyo, Japan), in terms of hue (hue angle, $\mathrm{h}^{\circ}$ ), lightness $\left(\mathrm{L}^{*}\right.$ ) and chroma $\left(\mathrm{C}^{*}\right)$, and readings were performed in the regions of the red color (more red side) and background color of fruits (less red side). PF, SI, TA, SS, respiratory and ethylene production rates were quantified according to methodology described in Thewes et al. (2015), with TA being expressed as $\%$ of malic acid. To obtain extracts for the CFT analysis, the protocol described in Stanger et al. (2018) was followed and its determination was performed using the Folin-Ciocalteau method, according to Roesler et al. (2007). The determination of total anthocyanins was performed according to methodology adapted by Fuleki and Francis (1968). About $2.5 \mathrm{~g}$ of peel sample, added to $15 \mathrm{~mL}$ of ethanol / distilled water $(95: 5, \mathrm{v} / \mathrm{v})$, acidified in ethanol / acid ratio of 85:15 (v/v) with hydrochloric acid $(\mathrm{HCl}, 1.5 \mathrm{~N})$ were used. Samples were homogenized in ultraturrax, kept for $24 \mathrm{~h}$ at $4^{\circ} \mathrm{C}$ and sent for centrifugation, also at $4^{\circ} \mathrm{C}$, for 20 minutes at $12,000 \mathrm{rpm}$. About $2.0 \mathrm{~mL}$ of supernatant was used, transferred to volumetric flask and completed to $50 \mathrm{~mL}$ with the extractive solvent. Readings were performed in spectrophotometer at wavelengths of $535 \mathrm{~nm}$ and $700 \mathrm{~nm}$.

Data were submitted to analysis of variance (ANOVA), whose significant means $(\mathrm{p}<0.05)$ were compared by the Scott-Knott test at 5\% error probability using the Sisvar statistical software, version 5.6 (FERREIRA, 2010). Percentage data were transformed by the formula: arc sine $[(x+1) / 100]^{1 / 2}$ before being submitted to ANOVA.

\section{Results and discussion}

In the $2015 / 2016$ season, due to favorable climatic conditions such as greater thermal amplitude observed during fruit maturation (Figure 1), the development of red color in 'Daiane' and 'Venice' apples was satisfactory. Almost $90 \%$ of fruits of both cultivars had more than $80 \%$ red color, and there were no differences among treatments for this attribute in the above $50 \%$ red color category (Table 2). However, the fraction of 'Daiane' apples in the above $80 \%$ red color category was higher in Biostimulant I, Biostimulant II and Foliar Fertilizer I + Foliar Fertilizer II treatments. In the same category, treatments presented no differences for the Venice cultivar.

In the 2016/2017 season, the fraction of 'Daiane' apples with red-colored peel in the above $50 \%$ category was higher with Foliar Fertilizer I + Foliar Fertilizer II, Biostimulant II and ethephon treatments, with no differences among treatments (Table 2). These treatments increased the percentage of 'Daiane' apples with more than $80 \%$ red color in relation to control, and ethephon was superior to the other treatments. In the 'Venice' cultivar, Biostimulant I and Foliar Fertilizer I + Foliar Fertilizer II treatments presented percentage of fruits with more than $80 \%$ red color inferior to ethephon, but superior to the other treatments. For fruits in the above $50 \%$ red color category, Biostimulant I and ethephon treatments were superior to the others and without differences from each other for 'Venice' fruits.

The mineral nutrient complex that makes up formulations of foliar fertilizers I and II treatments is vast, but the positive effect on the red coloration of 'Daiane' and 'Venice' apples may be related to the presence of boron (B) in the composition of Foliar Fertilizer I. Foliar $\mathrm{B}$ applications promote improvements in the red color of apples, advancing fruit maturation. Biostimulant II, which increased the percentage of red color of 'Daiane' apples, is a product developed for this purpose, and its composition presents some amino acids such as phenylalanine and methionine, which are initial substrates for phenylalanine ammonia lyase (PAL) enzyme and ethylene biosynthesis, respectively. Several enzymes involved in the biosynthesis of secondary metabolites compete with each other for common substrates, such as phenylalanine, hydroxycinnamic acids, benzoic acid derivatives and various stilbenoids, including anthocyanin biosynthesis (SCHIJLEN et al., 2004). Shafiq and Singh (2018) applied precursors and intermediates of the secondary metabolite biosynthesis pathway and concluded that the exogenous application of phenylalanine during the maturation period increased anthocyanin synthesis and red coloration of 'Cripps Pink' apples without changing fruit quality. However, the formulation of Biostimulant I, which increased the red coloration of 'Daiane' apples in the first harvest and of 'Venice' apples in the second 
harvest, is potassium oxide. Potassium $(\mathrm{K})$ is the main nutrient related to the color of apples and, according to Nava, Dechen and Nachtigall (2008), despite the high K content naturally present in Brazilian soils, potassium fertilization generally increases the quality of apples. Different effects between the first and second harvests demonstrate that environmental factors may influence the action of biostimulants, depending on the cultivar.

In some countries, to increase coating and improve the red color of apples, ethephon growth regulator is used, which releases and induces the autocatalytic synthesis of ethylene in plants. Ethylene coordinates fruit maturation involving complex metabolic and physiological changes that contribute to the formation of various flavonoids. However, the application of ethephon stimulates the activity of some enzymes of the anthocyanin biosynthesis pathway and seems to increase the production of anthocyanin more than other flavonoids (LIU et al., 2012).

In the 2016/2017 season, ethephon also increased the red color of 'Daiane' and 'Venice' apples and turned their red color darker, as verified by the lower $\mathrm{h}^{\circ}$ and $\mathrm{L} *$ values, respectively (Table 3 ). In the 'Daiane' cultivar, all treatments provided fruits with lower of $\mathrm{h}^{\circ}$ and $\mathrm{L} *$ values in relation to control treatment, and Biostimulant II and ethephon presented lower values than the other treatments. Also in 'Daiane' cultivar, all treatments increased the red saturation $\left(\mathrm{C}^{*}\right)$ in relation to control. In the 'Venice' cultivar, treatment with ethephon reduced red saturation in apple peels. As the synthesis of anthocyanins begins to cover the peel of apples with red hue, their lightness decreases and their saturation increases, making the red color more intense (GONZÁLEZ-TALICE; YURI; DEL POZO, 2013). However, ethylene changes the wax composition of the fruit cuticle and apples treated with ethephon may present reduced lightness and color saturation (LI et al., 2017).

In relation to the background color of apples, in the 2016/2017 season, treatment of ethephon increased the yellowing of 'Daiane' and 'Venice' cultivars, verified by the lower $\mathrm{h}^{\circ}$ value (Table 3 ). This event is related to the evolution of maturation promoted by ethylene (STEFFENS et al., 2006). The background color of the peel is relevant in the evaluation of fruit maturation, because during its development, the chlorophyll content present in the peel and pulp begins to decrease and yellow pigments become perceptible (IWANAMI, 2011). In the 'Daiane' cultivar, the preservation of the background color with greener hue occurred in the control treatment and in fruits treated with Biostimulant II and $\mathrm{KCl}$, while in 'Venice' cultivar, except for ethephon, no treatment presented differences for $\mathrm{h}{ }^{\circ}$ values. In 'Venice' cultivar, the saturation of the background color of ethephon-treated fruits was higher in relation to the other treatments, intensifying the yellowing caused by ethylene. The background color yellowing is a negative attribute induced by ethephon, because in addition to reducing the post-harvest life of fruits, the interest of consumers also reduces, since yellow color leads to the sensation of excessively mature fruits (LI et al., 2017).

In the 'Daiane' cultivar, ANT synthesis in fruit peels was also superior in all treatments in relation to control (Figure 2), presenting behavior similar to $\mathrm{h}{ }^{\circ}$ values in the redder fruit region (Table 3 ) in the 2016/2017 season. The similarity between anthocyanin synthesis and hue angle was also found by other authors (FELICETTI; SCHRADER, 2008; RYU et al., 2017). However, Biostimulant I and $\mathrm{KCl}$, which presented fruits with anthocyanin contents higher than control, did not provide an increase in the percentages of peel coating with red coloration. According to Ryu et al. (2017), chromatic characteristics are less sensitive than anthocyanin levels in some apple cultivars, so anthocyanins are not the only factor that determines the red coloration of fruits. Fruits treated with ethephon presented the highest amount of anthocyanins in relation to all treatments in both cultivars. Studies have shown that the syntheses of anthocyanins and ethylene are closely related; however, it is not yet clear how ethylene signaling stimulates the synthesis of anthocyanins in apple peels (HONDA, MORIYA, 2018); what is known is that it promotes the activity of several enzymes that catalyze the biosynthesis of anthocyanins in fruits (LIU et al., 2012). In the 'Venice' cultivar, fruits treated with $\mathrm{KCl}$ did not differ in anthocyanin content from ethephon-treated fruits. K may act as a cofactor for the activity of some specific enzyme of the anthocyanin biosynthesis process (HUNSCHE; BRACKMANN; ERNANI, 2003); however, the anthocyanin content also did not provide an increase in the percentage of redcolored fruits treated with $\mathrm{KCl}$.

In 2016/2017 season, ethephon also increased the synthesis of CFT in the peel of 'Daiane' fruits in relation to the other treatments, followed by Foliar Fertilizer I + Foliar II Fertilizer treatment (Figure 2). Tsao et al. (2005) attributed great importance to anthocyanins in the total phenolic compounds content. However, in the 'Venice' cultivar, the CFT content did not differ among treatments.

Fruits submitted to the application of ethephon in the 2016/2017 season presented the highest ethylene production rates in 'Daiane' and 'Venice' cultivars, and respiratory rates in 'Daiane' cultivar (Figure 3). In 'Daiane' apples, Biostimulant I and $\mathrm{KCl}$ treatments presented lower respiratory rate compared to the other treatments. Li et al. (2017) also found that ethephon accelerated respiration and ethylene production of 'Starkrimson' apples, evidencing that ethephon stimulates ethylene production, and that the increase in fruit respiration is directly related to the increase in ethylene production (BRACKMANN; STEFFENS; GIEHL, 2004). In the 'Venice' cultivar, the respiratory rate showed no difference among treatments. 
In the 2015/2016 season, the starch index and pulp firmness did not differ among treatments in both cultivars (Table 4). The SS contents did not differ among treatments in the 'Venice' cultivar; however, they were higher in fruits treated with Biostimulant I and Biostimulant II in relation to the other treatments for 'Daiane' apples. Blanke (2015) found similar results in increasing SS content with the application of Biostimulant II. This biostimulant has monosaccharides in its composition, whose application in apples can increase the activity of the primary metabolism (ROITSCH; GONZÁLEZ, 2004). The increase of primary metabolism may, in turn, increase the fruit's ability to accumulate sugars produced in leaves during photosynthesis, and increase the synthesis of organic acids that, during maturation, are converted into sugars. However, Biostimulant I may have increased the SS content of 'Daiane' apples due to the application of $\mathrm{K}$, which physiologically plays an important role in transporting sugars from leaves to fruits, being also related to maturation processes, which contribute to the accumulation of sugars in fruits (DE SOUZA et al., 2013). However, foliar application of $\mathrm{KCl}$ did not have the same effect. Perhaps some constituent of Biostimulant I favors foliar $\mathrm{K}_{2} \mathrm{O}$ absorption in relation to $\mathrm{KCl}$.

In the 2016/2017 season, pulp firmness again showed no difference among treatments for 'Daiane' and 'Venice' cultivars (Table 5). SS and TA also showed no difference among treatments for 'Venice' cultivar. Steffens et al. (2006) reported that the process of acid degradation may not be greatly influenced by ethylene. According to De Martin et al. (2018), a characteristic of 'Venice' fruits is the high pulp firmness, which may not be easily influenced by treatments tested. For 'Daiane' cultivar, Foliar Fertilizer I + Foliar Fertilizer II and ethephon treatments increased the SS content in fruits, and together with Biostimulant II treatment, reduced TA in relation to the other treatments.
The lower TA of these treatments is partly justified by the use of organic acids as substrate for respiration, since fruits treated with Biostimulant II, Foliar Fertilizer I + Foliar II and ethephon presented higher respiratory rate (Figure 3 ). On the other hand, fruits treated with Biostimulant I and $\mathrm{KCl}$ presented reduced respiratory rate in relation to the other treatments, and the highest TA values. Therefore, the low fruit respiratory rate of these two treatments must be related to some process of acid degradation, since malic acid represents a potential substrate for the respiration of apple fruits (ACKERMANN; FISCHER; AMADO, 1992). $\mathrm{K}$ may have reduced the respiratory rate of apples, which has resulted in slow acid degradation in these treatments. Hunsche, Brackmann and Ernani (2003) observed that fruits with lower $\mathrm{K}$ contents presented higher respiratory rate.

'Daiane' and 'Venice' fruits treated with ethephon showed higher starch index values in 2016/2017 (Table 5 ). The higher starch degradation in apples treated with ethephon is related to the release of ethylene and the promotion of maturation, being another unfavorable consequence of ethephon, since it reduces the longevity of apples during the post-harvest period (LI et al., 2017). On the other hand, Biostimulant II reduced the starch index in 'Daiane' apples. Schuhknecht et al. (2018) found that Biostimulant II had no effect on starch degradation in 'Braeburn' apples, and concluded that the product does not accelerate the maturation process. Foliar fertilizer I + foliar fertilizer II treatment, the former with B in its composition, also did not accelerate the maturation of 'Daiane' apples, according to the starch index in both seasons evaluated. It is possible that cobalt $(\mathrm{Co})$, present in foliar fertilizer II, reduces ethylene biosynthesis, since Co blocks the conversion of ACC into ethylene (GAD; MOHAMMED; BEKBAYEVA, 2013).

Table 1 - Compositions and doses of the treatments of biostimulants and foliar fertilizers, during maturation in 'Daiane' and 'Venice' apple trees. Caçador-SC.

\begin{tabular}{|c|c|c|c|}
\hline Treatment & Commercial name & Composition $\left(\mathrm{g} \mathrm{L}^{-1}\right)$ & Fractional dose (ha) \\
\hline Control & - & - & Untreated \\
\hline Biostimulant I & Potasium-S King ${ }^{\circledR}$ & 42 of $\mathrm{N} ; 364$ of $\mathrm{K}_{2} \mathrm{O}$ & $4 \mathrm{~L}+4 \mathrm{~L}+4 \mathrm{~L}+4 \mathrm{~L}$ \\
\hline \multirow{2}{*}{$\begin{array}{l}\text { Foliar fertilizer I + } \\
\text { Foliar fertilizer II }\end{array}$} & Mover $^{\circledR}+$ & $\begin{array}{l}63 \text { of } \mathrm{N} ; 50.4 \text { of B; } 2.14 \text { of } \mathrm{Cu} \\
0.18 \text { of } \mathrm{Mo} ; 37.8 \text { of } \mathrm{Zn} .\end{array}$ & $3 \mathrm{~L}+3 \mathrm{~L}+3 \mathrm{~L}+3 \mathrm{~L}$ \\
\hline & Hold $^{\circledR}$ & $\begin{array}{l}33.2 \text { of } \mathrm{N} ; 64 \text { of } \mathrm{P}_{2} \mathrm{O}_{5} ; 12.8 \text { of } \mathrm{S} \\
25.6 \text { of } \mathrm{Co} ; 38.4 \text { of Mo. }\end{array}$ & $2 \mathrm{~L}+2 \mathrm{~L}+2 \mathrm{~L}+2 \mathrm{~L}$ \\
\hline Biostimulant II & Sunred $^{\circledR}$ & $\begin{array}{l}26.6 \text { of } \mathrm{N} ; 93.1 \text { of } \mathrm{K}_{2} \mathrm{O} ; 86.2 \\
\text { of organic } \mathrm{C} \text {; methionine; } \\
\text { phenylalanine; oxylipines; } \\
\text { monosaccharides. }\end{array}$ & $4 \mathrm{~L}+4 \mathrm{~L}+4 \mathrm{~L}+4 \mathrm{~L}$ \\
\hline $\mathrm{KCl}$ & - & - & $20 \mathrm{~kg}+20 \mathrm{~kg}+20 \mathrm{~kg}+20 \mathrm{~kg}$ \\
\hline Ethephon* & Ethrel $^{\circledR}$ & 240 de etefon. & $480 \mathrm{~g}$ \\
\hline
\end{tabular}

*Treatment of ethephon was applied only in 2016/2017 season. 
Table 2 - Percentage of 'Daiane' and 'Venice' apples with red peel covering above $50 \%$ and $80 \%$ in the harvest, due to applications of biostimulants and foliar fertilizers, during maturation, in two seasons. Caçador-SC.

\begin{tabular}{|c|c|c|c|c|}
\hline \multirow{3}{*}{ Treatment } & \multicolumn{4}{|c|}{ Red coloring on the fruit peel $(\%)$} \\
\hline & $>50 \%$ & $>80 \%$ & $>50 \%$ & $>80 \%$ \\
\hline & \multicolumn{2}{|c|}{ Daiane } & \multicolumn{2}{|c|}{ Venice } \\
\hline & \multicolumn{4}{|c|}{$2015 / 2016$} \\
\hline Control & $95.1^{\mathrm{ns}}$ & $79.6 \mathrm{~b}$ & $99.3^{\text {ns }}$ & $87.3^{\text {ns }}$ \\
\hline Biostimulant I (4 L ha-1)* & 99.6 & $97.3 \mathrm{a}$ & 99.7 & 91.7 \\
\hline $\begin{array}{l}\text { Foliar fertilizer I }\left(3 \mathrm{~L} \mathrm{ha}^{-1}\right)^{*}+ \\
\text { Foliar fertilizer II }\left(2 \mathrm{~L} \mathrm{ha}^{-1}\right)^{*}\end{array}$ & 99.3 & $91.5 \mathrm{a}$ & 97.4 & 85.7 \\
\hline Biostimulant II $\left(4 \mathrm{~L} \mathrm{ha}^{-1}\right)^{*}$ & 99.5 & $94.8 \mathrm{a}$ & 100.0 & 90.0 \\
\hline $\mathrm{KCl}\left(20 \mathrm{~kg} \mathrm{ha}^{-1}\right)^{*}$ & 96.1 & $82.0 \mathrm{~b}$ & 98.3 & 90.8 \\
\hline \multirow[t]{2}{*}{$\mathrm{CV}(\%)$} & 8.2 & 16.0 & 6.1 & 12.0 \\
\hline & \multicolumn{4}{|c|}{$2016 / 2017$} \\
\hline Control & $71.8 \mathrm{~b}$ & $25.5 \mathrm{c}$ & $82.6 \mathrm{~b}$ & $31.1 \mathrm{c}$ \\
\hline Biostimulant I (4 L ha' $)^{*}$ & $69.4 \mathrm{~b}$ & $25.8 \mathrm{c}$ & $91.1 \mathrm{a}$ & $48.5 \mathrm{~b}$ \\
\hline $\begin{array}{l}\text { Foliar fertilizer I }\left(3 \mathrm{~L} \mathrm{ha}^{-1}\right)^{*}+ \\
\text { Foliar fertilizer II }\left(2 \mathrm{~L} \mathrm{ha}^{-1}\right)^{*}\end{array}$ & $89.6 \mathrm{a}$ & $41.6 \mathrm{~b}$ & $86.4 \mathrm{~b}$ & $40.7 \mathrm{~b}$ \\
\hline Biostimulant II $\left(4 \mathrm{~L} \mathrm{ha}^{-1}\right)^{*}$ & $87.5 \mathrm{a}$ & $43.3 \mathrm{~b}$ & $82.3 \mathrm{~b}$ & $29.2 \mathrm{c}$ \\
\hline $\mathrm{KCl}\left(20 \mathrm{~kg} \mathrm{ha}^{-1}\right)^{*}$ & $73.2 \mathrm{~b}$ & $19.8 \mathrm{c}$ & $86.5 \mathrm{~b}$ & $36.6 \mathrm{c}$ \\
\hline Ethephon $\left(480 \mathrm{~g} \mathrm{ha}^{-1}\right)$ & $93.4 \mathrm{a}$ & $66.6 \mathrm{a}$ & $95.1 \mathrm{a}$ & $67.8 \mathrm{a}$ \\
\hline$\overline{C V}(\%)$ & 16.0 & 26.0 & 9.4 & 10.7 \\
\hline
\end{tabular}

CV: coefficient of variation. Means followed by same letter do not differ by Scott-Knott test at 5\% probability. ns: not significant ( $>0.05$ ). *Doses applied four times.

Table 3 - Color attributes in the peel, in more and less red regions, of 'Daiane' and 'Venice' apples in the harvest, due to applications of biostimulants, foliar fertilizers and ethephon, during maturation, in 2016/2017 season. Caçador-SC.

\begin{tabular}{|c|c|c|c|c|c|c|}
\hline \multirow{2}{*}{ Treatment } & \multicolumn{2}{|c|}{ Lightness $\left(L^{*}\right)$} & \multicolumn{2}{|c|}{ Chroma $\left(C^{*}\right)$} & \multicolumn{2}{|c|}{ Tonality $\left(h^{\circ}\right)$} \\
\hline & Daiane & Venice & Daiane & Venice & Daiane & Venice \\
\hline & \multicolumn{6}{|c|}{ Red } \\
\hline Control & $50.3 \mathrm{a}$ & $40.4 \mathrm{a}$ & $36.1 \mathrm{~b}$ & $42.8 \mathrm{a}$ & $41.7 \mathrm{a}$ & $28.2 \mathrm{a}$ \\
\hline Biostimulant I $\left(4 \mathrm{~L} \mathrm{ha}^{-1}\right)^{*}$ & $47.1 \mathrm{~b}$ & $38.8 \mathrm{a}$ & $40.5 \mathrm{a}$ & $43.0 \mathrm{a}$ & $32.4 \mathrm{~b}$ & $26.9 \mathrm{a}$ \\
\hline $\begin{array}{l}\text { Foliar fertilizer I }\left(3 \mathrm{~L} \mathrm{ha}^{-1}\right)^{*}+ \\
\text { Foliar fertilizer II }\left(2 \mathrm{~L} \mathrm{ha}^{-1}\right)^{*}\end{array}$ & $46.5 \mathrm{~b}$ & $39.9 \mathrm{a}$ & $41.1 \mathrm{a}$ & $42.9 \mathrm{a}$ & $31.8 \mathrm{~b}$ & $27.4 \mathrm{a}$ \\
\hline Biostimulant II $\left(4 \mathrm{~L} \mathrm{ha}^{-1}\right)^{*}$ & $42.5 \mathrm{c}$ & $39.8 \mathrm{a}$ & $40.5 \mathrm{a}$ & $41.7 \mathrm{a}$ & $29.0 \mathrm{c}$ & $27.4 \mathrm{a}$ \\
\hline $\mathrm{KCl}\left(20 \mathrm{~kg} \mathrm{ha}^{-1}\right)^{*}$ & $46.3 \mathrm{~b}$ & $39.4 \mathrm{a}$ & $40.3 \mathrm{a}$ & $42.5 \mathrm{a}$ & $33.2 \mathrm{~b}$ & $28.0 \mathrm{a}$ \\
\hline Ethephon $\left(480 \mathrm{~g} \mathrm{ha}^{-1}\right)$ & $39.4 \mathrm{~d}$ & $37.5 \mathrm{~b}$ & $40.3 \mathrm{a}$ & $39.7 \mathrm{~b}$ & $26.6 \mathrm{c}$ & $25.0 \mathrm{~b}$ \\
\hline \multirow[t]{2}{*}{$\mathrm{CV}(\%)$} & 4.2 & 3.2 & 4.3 & 3.9 & 9.0 & 4.7 \\
\hline & \multicolumn{6}{|c|}{ Background color (yellow) } \\
\hline Control & $75.4^{\mathrm{ns}}$ & $74.2^{\mathrm{ns}}$ & $37.3^{\mathrm{ns}}$ & $36.7 \mathrm{~b}$ & $105.0 \mathrm{a}$ & $96.6 \mathrm{a}$ \\
\hline Biostimulant I $\left(4 \mathrm{~L} \mathrm{ha}^{-1}\right)^{*}$ & 73.3 & 75.2 & 33.9 & $36.1 \mathrm{~b}$ & $100.5 \mathrm{~b}$ & $94.0 \mathrm{a}$ \\
\hline $\begin{array}{l}\text { Foliar fertilizer I }\left(3 \mathrm{~L} \mathrm{ha}^{-1}\right)^{*}+ \\
\text { Foliar fertilizer II }\left(2 \mathrm{~L} \mathrm{ha}^{-1}\right)^{*}\end{array}$ & 75.5 & 74.0 & 34.6 & $37.1 \mathrm{~b}$ & $99.3 \mathrm{~b}$ & $97.0 \mathrm{a}$ \\
\hline Biostimulant II $\left(4 \mathrm{~L} \mathrm{ha}^{-1}\right)^{*}$ & 75.5 & 74.0 & 35.1 & $36.0 \mathrm{~b}$ & $102.5 \mathrm{a}$ & $95.3 \mathrm{a}$ \\
\hline $\mathrm{KCl}\left(20 \mathrm{~kg} \mathrm{ha}^{-1}\right)^{*}$ & 76.2 & 73.9 & 36.6 & $36.1 \mathrm{~b}$ & $105.1 \mathrm{a}$ & $94.7 \mathrm{a}$ \\
\hline Ethephon $\left(480 \mathrm{~g} \mathrm{ha}^{-1}\right)$ & 75.3 & 72.4 & 33.0 & $42.4 \mathrm{a}$ & $94.3 \mathrm{c}$ & $84.9 \mathrm{~b}$ \\
\hline $\mathrm{CV}(\%)$ & 4.3 & 2.4 & 7.5 & 4.0 & 3.8 & 4.4 \\
\hline
\end{tabular}

$\mathrm{CV}$ : coefficient of variation. Means followed by same letter do not differ by Scott-Knott test at $5 \%$ probability. ns: not significant ( $>0.05$ ).

* Doses applied four times. 
Table 4 - Starch index (SI), pulp firmness (FP) and soluble solids (SS) of 'Daiane' and 'Venice' apples in the harvest, due to applications of biostimulants and foliar fertilizers, during maturation, in 2015/2016 season. Caçador-SC.

\begin{tabular}{lcccccc}
\hline \multicolumn{1}{c}{ Tratamento } & \multicolumn{2}{c}{ SI (1-10) } & \multicolumn{2}{c}{ FP $(\mathbf{N})$} & \multicolumn{2}{c}{ SS $\left({ }^{\circ}\right.$ Brix $)$} \\
\hline & Daiane & Venice & Daiane & Venice & Daiane & Venice \\
Control & $5.8^{\mathrm{ns}}$ & $6.1^{\mathrm{ns}}$ & $68.1^{\mathrm{ns}}$ & $84.4^{\mathrm{ns}}$ & $13.8 \mathrm{~b}$ & $14.5^{\mathrm{ns}}$ \\
Biostimulant I $\left(4 \mathrm{~L} \mathrm{ha}^{-1}\right)^{*}$ & 6.8 & 5.2 & 65.0 & 78.2 & $15.0 \mathrm{a}$ & 14.2 \\
Foliar fertilizer I $\left(3 \mathrm{~L} \mathrm{ha}^{-1}\right)^{*}+$ & 6.0 & 6.2 & 66.3 & 81.8 & $14.3 \mathrm{~b}$ & 14.8 \\
Foliar fertilizer II $\left(2 \mathrm{~L} \mathrm{ha}^{-1}\right)^{*}$ & 6.7 & 6.4 & 63.6 & 79.1 & $14.9 \mathrm{a}$ & 14.5 \\
Biostimulant II $\left(4 \mathrm{~L} \mathrm{ha}^{-1}\right)^{*}$ & 6.1 & 5.1 & 69.9 & 84.4 & $13.8 \mathrm{~b}$ & 14.3 \\
$\mathrm{KCl}\left(20 \mathrm{~kg} \mathrm{ha}^{-1}\right)^{*}$ & 15.7 & 26.7 & 8.3 & 4.9 & 2.6 & 2.2 \\
\hline $\mathrm{CV}(\%)$ & & & & & &
\end{tabular}

CV: coefficient of variation. Means followed by same letter do not differ by Scott-Knott test at 5\% probability. ns: not significant (p>0.05). *Doses applied four times.

Table 5 - Starch index (SI), pulp firmness (FP), soluble solids (SS) and titratable acidity (TA) of 'Daiane' and 'Venice' apples in the harvest, due to applications of biostimulants, foliar fertilizers and ethephon, during maturation, in 2016/2017 season. Caçador-SC.

\begin{tabular}{lccccccccc}
\hline \multicolumn{1}{c}{ Tratamento } & \multicolumn{2}{c}{ SI (1-5) } & \multicolumn{2}{c}{ PF (N) } & \multicolumn{2}{c}{ SS ('Brix) } & \multicolumn{2}{c}{ TA (\%) } \\
\hline & Daiane & Venice & Daiane & Venice & Daiane & Venice & Daiane & Venice \\
Control & $4.0 \mathrm{~b}$ & $4.1 \mathrm{~b}$ & $80.7^{\mathrm{ns}}$ & $84.4^{\mathrm{ns}}$ & $12.4 \mathrm{~b}$ & $12.9^{\mathrm{ns}}$ & $0.31 \mathrm{a}$ & $0.36^{\mathrm{ns}}$ \\
Biostimulant I $\left(4 \mathrm{~L} \mathrm{ha}^{-1}\right)^{*}$ & $4.0 \mathrm{~b}$ & $4.1 \mathrm{~b}$ & 77.3 & 80.2 & $12.7 \mathrm{~b}$ & 12.5 & $0.30 \mathrm{a}$ & 0.32 \\
Foliar fertilizer I $\left(3 \mathrm{~L} \mathrm{ha}^{-1}\right)^{*}+$ & $4.0 \mathrm{~b}$ & $3.9 \mathrm{~b}$ & 80.2 & 85.2 & $13.0 \mathrm{a}$ & 12.9 & $0.28 \mathrm{~b}$ & 0.34 \\
Foliar fertilizer II $\left(2 \mathrm{~L} \mathrm{ha}^{-1}\right)^{*}$ & $3.6 \mathrm{c}$ & $3.8 \mathrm{~b}$ & 77.6 & 88.3 & $12.6 \mathrm{~b}$ & 13.1 & $0.28 \mathrm{~b}$ & 0.35 \\
Biostimulant II $\left(4 \mathrm{~L} \mathrm{ha}^{-1}\right)^{*}$ & $4.0 \mathrm{~b}$ & $4.2 \mathrm{~b}$ & 81.7 & 83.5 & $12.2 \mathrm{~b}$ & 13.0 & $0.33 \mathrm{a}$ & 0.35 \\
$\mathrm{KCl}\left(20 \mathrm{~kg} \mathrm{ha}^{-1}\right)^{*}$ & $4.5 \mathrm{a}$ & $4.6 \mathrm{a}$ & 78.1 & 84.7 & $13.4 \mathrm{a}$ & 13.6 & $0.25 \mathrm{~b}$ & 0.35 \\
Ethephon $\left(480 \mathrm{~g} \mathrm{ha}^{-1}\right)$ & 7.0 & 6.0 & 4.1 & 6.4 & 3.1 & 4.5 & 10.2 & 9.8 \\
\hline CV $(\%)$ & & & & & & & & &
\end{tabular}

CV: coefficient of variation. Means followed by same letter do not differ by Scott-Knott test at 5\% probability. ns: not significant ( $>0.05$ ). $*$ Doses applied four times. 

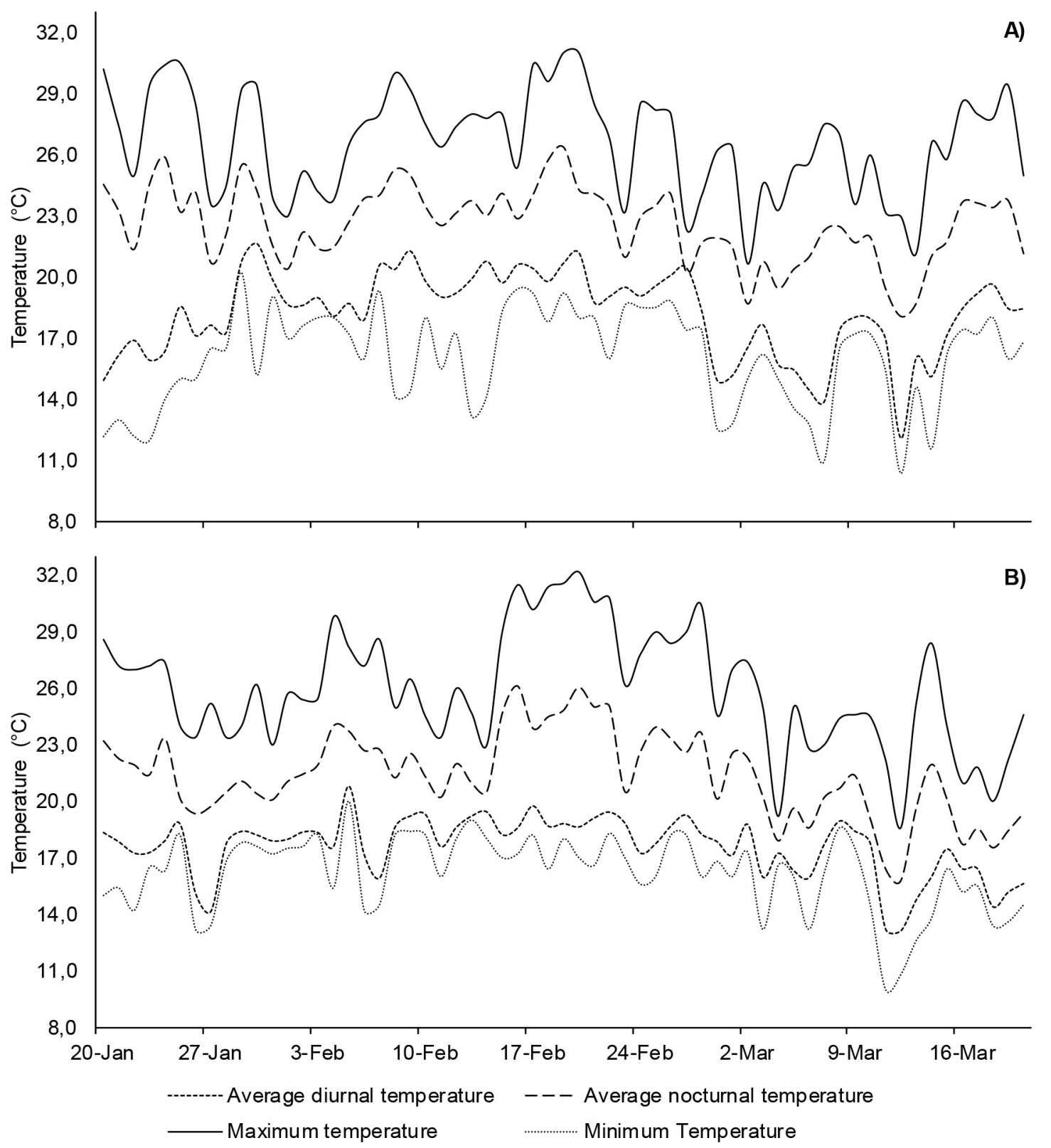

Figure 1 - Maximum and minimum daily temperatures and average nocturnal and diurnal temperatures during fruit maturation in 2015/2016 (A) and 2016/2017 (B) seasons, in Caçador-SC. Source: INMET. 


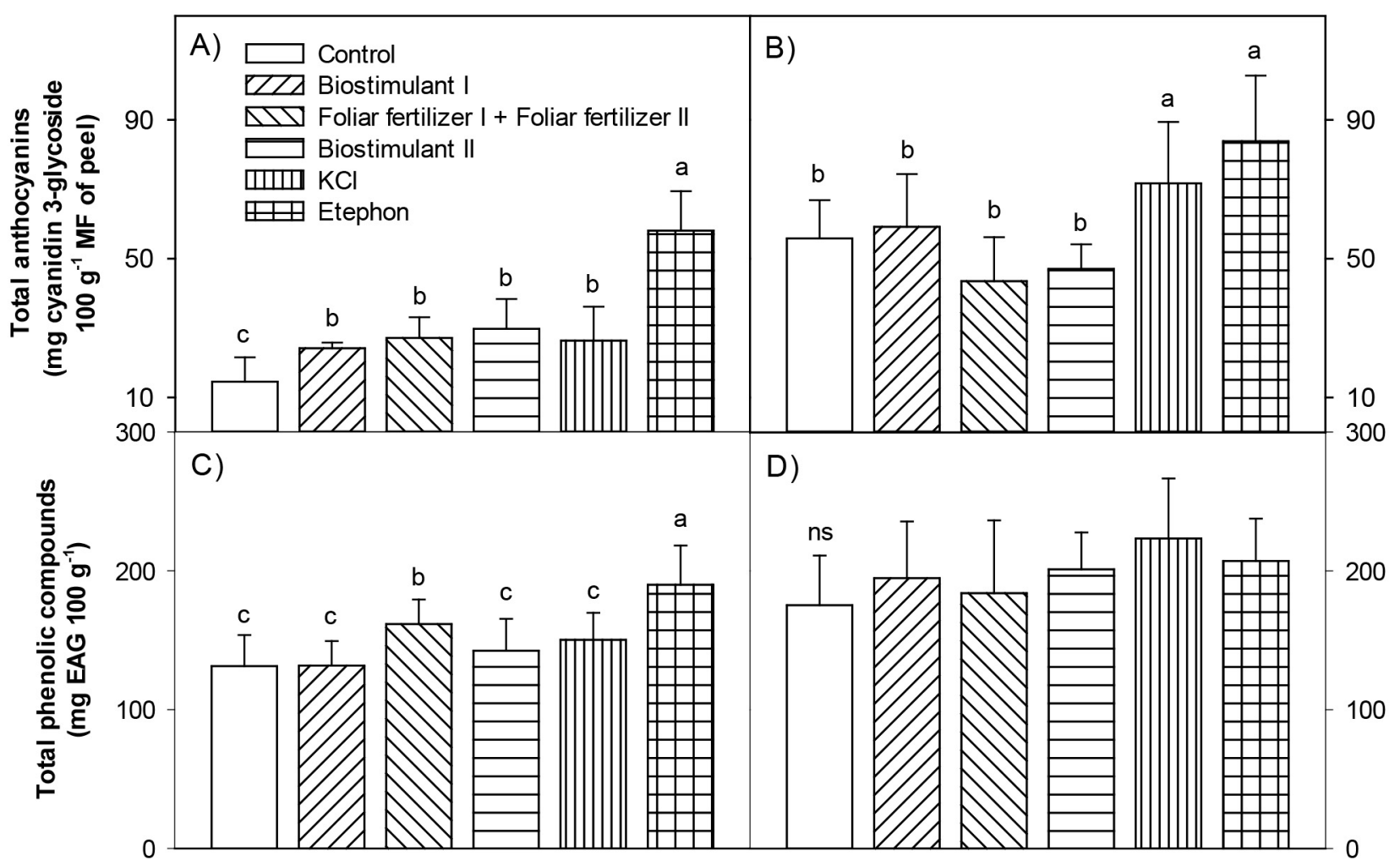

Figure 2 - Total anthocyanins and total phenolic compounds contents in 'Daiane' (A and C) and 'Venice' (B and D) apples, respectively, at harvest, due to applications of biostimulants, foliar fertilizers and ethephon during maturation, in 2016/2017 season. Caçador-SC.

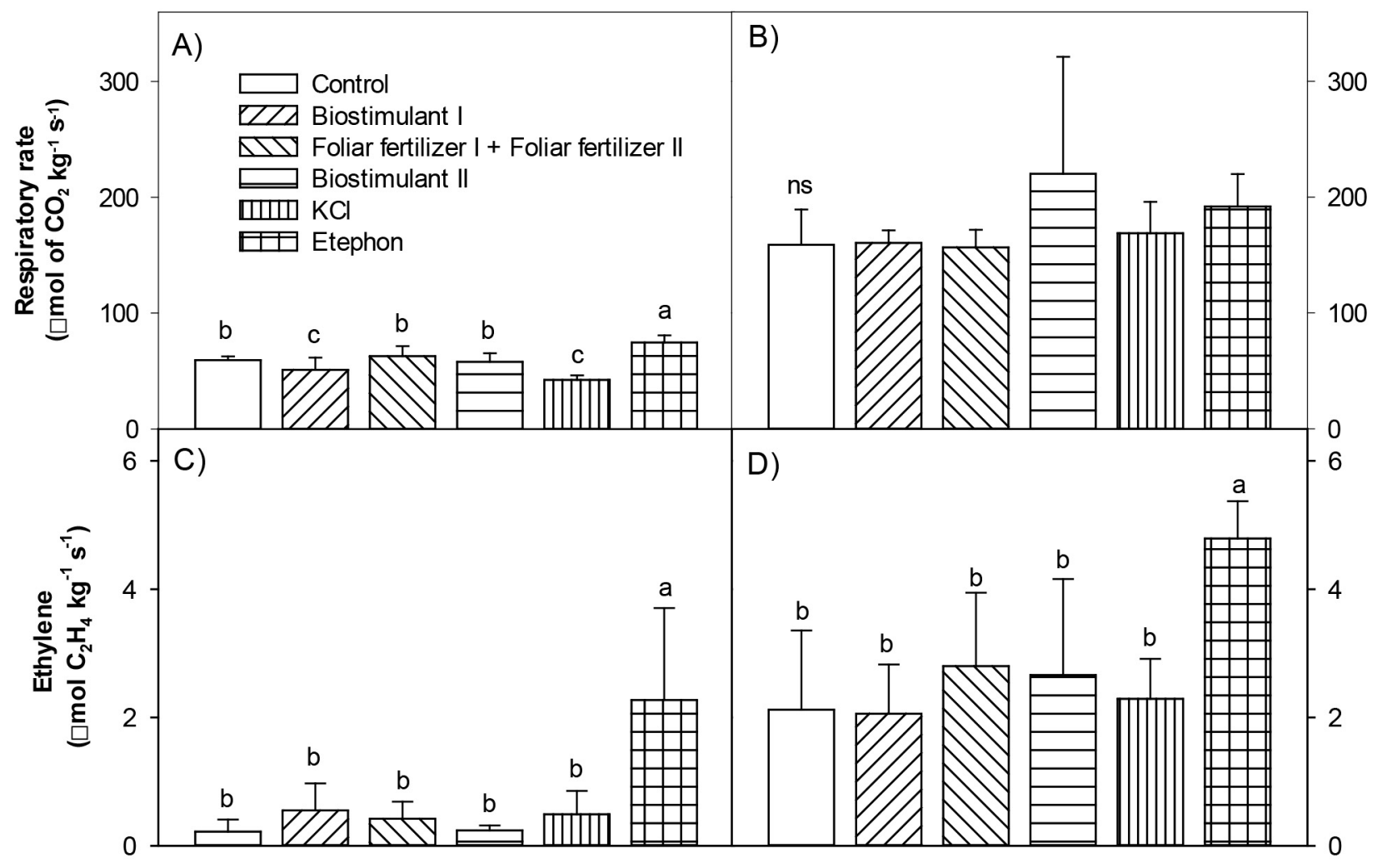

Figure 3 - Respiratory and ethylene production rates of 'Daiane' (A and C) and 'Venice' (B and D) apples, respectively, at harvest, due to applications of biostimulants, foliar fertilizers and ethephon during maturation, in 2016/2017 season. Caçador-SC. 


\section{Conclusion}

The use of biostimulants and foliar fertilizers as an alternative to increase the red coloration in the apple peel depends on the cultivar and varies according to the climatic conditions of each season. Biostimulants and foliar fertilizers do not accelerate the maturation of 'Daiane' and 'Venice' apples; however, further studies are needed to understand the effect of products in relation to climatic variations and post-harvest fruit behavior.

Ethephon increases the red coloration of the fruit peel of 'Daiane' and 'Venice' cultivars; however, it accelerates fruit maturation. Ethephon is an alternative to increase the quality of 'Daiane' and 'Venice' apples, but may reduce post-harvest fruit longevity.

\section{Acknowledgments}

To CAPES and FUMDES for granting scholarships.

\section{References}

ACKERMANN, J.; FISCHER, M.; AMADO, R. Changes in sugars, acids, and amino acids during ripening and storage of apples (cv. Glockenapfel). Journal of Agricultural and Food Chemistry, Washington, v.40, n.7, p.1131-1134, 1992.

BLANKE, M. Biostimulantien-von Algenextrakten bis Shrimpsschalen-eine Branche (er-) findet sichBiostimulants-a wide range from algae extracts to shrimp shells. Erwerbs-Obstbau, Berlim, v.58, n.2, p.81-87, 2016.

BLANKE, M. Möglichkeiten zur Verbesserung der Rotfärbung bei Äpfeln. Erwerbs-Obstbau, Berlim, v.57, n.2, p.47-62, 2015.

BRACKMANN, A.; STEFFENS, C.A.; GIEHL, R.F.H. Maturação da maçã Fuji em função do atraso na colheita e da aplicação pré-colheita de aminoetoxivinilglicina. Ciência Rural, Santa Maria, v.34, n.3, p.737-742, 2004.

CHEN, B.; MAO, J.; HUANG, B.; MI, B.; LIU, Y.; HU, Z.; MA, Z. Effect of bagging and time of harvest on fruit quality of'Red Fuji'apple in high altitude area in China. Fruits, Paris, v.72, n.1, p.36-46, 2017.

DE MARTIN, M.S.; BETINELLI, K.S.; ARGENTA, L.C.; STEFFENS, C.A.; AMARANTE, C.V.T.; KVITSCHAL, M.V.Storage potential of 'SCS426 Venice' apples under different storage technologies. Revista Brasileira de Fruticultura, Jaboticabal, v.40, n.2, p.1-10, 2018.
DE SOUZA, F.; ARGENTA, L.C.; NAVA, G.; ERNANI, P.R.; DO AMARANTE, C.V.T. Qualidade de maçãs' fuji'influenciada pela adubação nitrogenada e potássica em dois tipos de solo. Revista Brasileira de Fruticultura, Jaboticabal, v.35, n.1, p.305-315, 2013.

FALLAHI, E.; FALLAHI, B.; NEILSEN, G.H.; NEILSEN, D.; PERYEA, F.J. Effects of mineral nutrition on fruit quality and nutritional disorders in apples. Acta Horticulturae, Wageningen, n.868, p.49-60, 2010.

FELICETTI, D.A.; SCHRADER, L.E. Changes in pigment concentrations associated with the degree of sunburn browning of 'Fuji'apple. Journal of the American Society for Horticultural Science, Washington, v.133, n.1, p.27-34, 2008.

FERREIRA, D. F. Sisvar-programa estatístico. Versão 5.6 (Build 86). Lavras: Universidade Federal de Lavras, 2010

FULEKI, T.; FRANCIS, F. Quantitative methods for anthocyanins. Journal of Food Science, New York, v.33, n.3, p.266-274, 1968.

GAD, N.; MOHAMMED, A.M.; BEKBAYEVA, L.K. Role of cobalt on cowpea growth and yield under different levels of nitrogen. World Applied Sciences Journal, Faisalabad, v.22, n.4, p.470-478, 2013.

GONZÁLEZ-TALICE, J.; YURI, J.A.; DEL POZO, A. Relations among pigments, color and phenolic concentrations in the peel of two Gala apple strains according to canopy position and light environment. Scientia Horticulturae, Amsterdam, v.151, p.83-89, 2013.

HONDA, C.; MORIYA, S. Anthocyanin biosynthesis in apple fruit. The Horticulture Journal, Tokyo, v.87, n.3, p.305-314, 2018.

HUNSCHE, M.; BRACKMANN, A.; ERNANI, P.R. Efeito da adubação potássica na qualidade pós-colheita de maçãs' Fuji'. Pesquisa Agropecuária Brasileira, Brasília, DF, v.38, n.4, p.489-496, 2003.

IWANAMI, H. Breeding for fruit quality in apple. Breeding for Fruit Quality, Hoboken, p.173-200, 2011.

KVITSCHAL, M.V.; DENARDI, F. Necessidade de diversificação de cultivares de macieira no Brasil. Revista Agropecuária Catarinense, Florianópolis, v.25, n.2, p.78-84, 2010. 
LI, F.; MIN, D.; SONG, B.; SHAO, S.; ZHANG, X. Ethylene effects on apple fruit cuticular wax composition and content during cold storage. Postharvest Biology and Technology, Amsterdam, v.134, p.98-105, 2017.

LIU, J.; WEI, J.; LIU, M.; SONG, Y.; FENG, S.; WANG, C.; CHEN, X.-S. The relationships between the enzyme activity of anthocyanin biosynthesis, ethylene release and anthocyanin accumulation in fruits of precocious apple cultivars. Acta Horticulturae Sinica, Bejing, v.39, n.7, p.1235-1242, 2012.

MUSACCHI, S.; SERRA, S. Apple fruit quality: Overview on pre-harvest factors. Scientia Horticulturae, Amsterdam, v.234, p.409-430, 2018.

NAVA, G.; DECHEN, A.R.; NACHTIGALL, G.R. Nitrogen and Potassium Fertilization Affect Apple Fruit Quality in Southern Brazil. Communications in Soil Science and Plant Analysis, New York, v.39, n.1-2, p.96-107, 2008.

ROESLER, R.; GOMES MALTA, L.; CARRASCO, L.C.; BARATA HOLANDA, R.; SOCORRO SOUSA, C.A.; PASTORE, G.M. Atividade antioxidante de frutas do cerrado. Ciência e Tecnologia de Alimentos, Campinas, v.27, n.1, p.53-60, 2007.

ROITSCH, T.; GONZÁLEZ, M.-C. Function and regulation of plant invertases: sweet sensations. Trends in Plant Science, Cambridge, v.9, n.12, p.606-613, 2004.

RYU, S.; HAN, H.-H.; JEONG, J.H.; KWON, Y.H.; HAN, J.H.; DO, G.R.; CHOI, I.-M.; LEE, H.J. Night temperatures affect fruit coloration and expressions of anthocyanin biosynthetic genes in 'Hongro' apple fruit skins. European Journal of Horticultural Science, Stuttgart, v.82, n.5, p.232-238, 2017.

SANHUEZA, R.M.V.; PROTAS, J.F.S.; FREIRE, J.M. Manejo da macieira no sistema de produção integrada de frutas. Bento Gonçalves: Embrapa Uva e Vinho, 2006. $164 p$.

SCHIJLEN, E.G.; DE VOS, C.R.; VAN TUNEN, A.J.; BOVY, A.G. Modification of flavonoid biosynthesis in crop plants. Phytochemistry, London, v.65, n.19, p.26312648, 2004.
SCHUHKNECHT, H.; DAMEROW, L.; KUNZ, A.; BLANKE, M. Einfluss von biostimulanzien und lichtreflexionsfolie auf die fruchtqualität und farbentwicklung bei apfel. Erwerbs-Obstbau, Berlim, v.60, n.2, p.89-103, 2018.

SHAFIQ, M.; SINGH, Z. Pre-harvest spray application of phenylpropanoids influences accumulation of anthocyanin and flavonoids in 'Cripps Pink' apple skin.Scientia Horticulturae, Amsterdam, v.233, p.141-148, 2018.

STANGER, M.C.; STEFFENS, C.A.; SOETHE, C.; MOREIRA, M.A.; DO AMARANTE, C.V.T.; BOTH, V.; BRACKMANN, A. Phenolic compounds content and antioxidant activity of 'Galaxy' apples stored in dynamic controlled atmosphere and ultralow oxygen conditions. Postharvest Biology and Technology, Amsterdam, v.144, p.70-76, 2018.

STEFFENS, C.A.; GUARIENTI, A.J.W.; STORCK, L.; BRACKMANN, A. Maturação da maçã'Gala'com a aplicação pré-colheita de aminoetoxivinilglicina e ethephon.Ciência Rural, Santa Maria, v.36, n.2, p.434440, 2006.

THEWES, F.R.; BOTH, V.; BRACKMANN, A.; WEBER, A.; DE OLIVEIRA ANESE, R. Dynamic controlled atmosphere and ultralow oxygen storage on 'Gala' mutants quality maintenance. Food Chemistry, London, v.188, p.62-70, 2015.

TSAO, R.; YANG, R.; XIE, S.; SOCKOVIE, E.; KHANIZADEH, S. Which polyphenolic compounds contribute to the total antioxidant activities of apple? Journal of Agricultural and Food Chemistry, Washington, v.53, n.12, p.4989-4995, 2005. 